\title{
Relationship Principal Leadership to Work Motivation, Morale Teacher and Teacher Performance of State Junior High Schools
}

\author{
Syamsudin Noor $^{1}$, Wahyu ${ }^{2}$, Suhaimi ${ }^{3}$ \\ Magister Program of Educational Manajement, Lambung Mangkurat University Banjarmasin, Indonesia
}

\begin{tabular}{|c|c|}
\hline ARTICLE INFO & A B S T R ACT \\
\hline $\begin{array}{l}\text { Article history } \\
\text { Received: June } \\
\text { Revised: August } \\
\text { Accepted: September } \\
\text { Keywords: } \\
\text { Principal Leadership, Work } \\
\text { Motivation, Morale Teacher, } \\
\text { Teacher Performance }\end{array}$ & $\begin{array}{l}\text { This study aims to Describe the Principal Leadership, work motivation, morale } \\
\text { and teacher performance in State Middle Schools in the East Banjarmasin sub- } \\
\text { district of Banjarmasin City. This study uses a quantitative approach with descrip- } \\
\text { tive methods. The total population of this study is I } 22 \text { teachers of SMP Negeri } \\
\text { East Banjarmasin, Banjarmasin City, sampling uses the sample proportional ran- } \\
\text { dom sampling technique, the data is collected using questionnaires. Analysis data } \\
\text { uses a Likert scale model. Reliability analysis was calculated by the Cronbach } \\
\text { Alpha formula The results of the study show that: (I) An overview of the leader- } \\
\text { ship of the principal in a Public Middle School in the East Banjarmasin sub- } \\
\text { district of Banjarmasin City The highest average value is } 4.63 \text {, the lowest average } \\
\text { value is } 4.32 \text {. (2) The picture of motivation has the highest average value of } 4.78 \\
\text { and the lowest average value of } 4.39 \text {. (3) The description of the teacher's work } \\
\text { spirit has the highest average value of } 4.71 \text { and the lowest average value of } 2.18 \text {. } \\
\text { (4) An overview of the performance of teachers has the highest average value of } \\
4.74 \text { and the lowest average value of } 4.39 \text {. (5) There is a significant relationship } \\
\text { between the leadership of the principal and the motivation of the work. ( } 6 \text { ) There } \\
\text { is a significant relationship between the leadership of the principal and the work- } \\
\text { ing morale. ( } 7 \text { ) Principal leadership is directly related significantly to the perfor- } \\
\text { mance of teachers. ( } 8 \text { ) There is a direct relationship between work motivation and } \\
\text { teacher performance. ( } 9 \text { ) There is a significant relationship between work enthusi- } \\
\text { asm and the performance of teachers. } \\
\text { The results of this study are expected to be useful in an effort to improve work } \\
\text { motivation, morale and teacher performance in carrying out teaching tasks and } \\
\text { indirectly improve leadership of the principal itself }\end{array}$ \\
\hline & $\begin{array}{l}\text { (C) (1) (-) } \begin{array}{l}\text { C2019 The Authors. Journal of K6, Education, and Management (j- } \\
\text { K6EM). ISSN: } 2580-2135 \text {. Published by Graduated Program of Educa- } \\
\text { tional Management, Universitas Lambung Mangkurat, Banjarmasin, }\end{array} \\
\text { Indonesia. This is an open access article under the open journal systems. }\end{array}$ \\
\hline
\end{tabular}

*Author correspondence: Syamsudin Noor; E-mail: syamudin284@gmail.com 


\section{Introduction}

Task Leaders include directing, mobilizing, influencing and empowering (4 M) members. Thus leadership in schools can be interpreted as a person's ability to move, direct, influence and empower the mindset and workings of teachers and school staff to be independent in working (Suhaimi, 2018). There are 4 indicators that must be fulfilled so that the principal is successful in carrying out his duties, namely: (I) Openness, (2) Attention to teachers and school staff, (3) Interactions and (4) Decision Makers. Principals can increase teacher motivation by: (I) Implementing open management, (2) Implementing job descriptions with clear tasks and functions, (3) Implementing vertical relations downward, (4) Mapping programs and activities to increase work motivation, (5) Continuous and comprehensive supervision, (6) Evaluation (Suriansyah, 2015). (Purwanto, 2009) said that leadership is a set of abilities to be used as a means of convincing that they lead so that they want and can carry out tasks with enthusiasm and in ner excitement, and feel forced.

These activities are expected to increase motivation, which in turn will have a positive impact on efforts to improve school performance. (Murtie, 2013) states that motivation is a stimulate that arises from within a human being to fulfill various needs. In carrying out his daily work a teacher must have a work spirit (Kusrini, 2018).

Morale teacher's is the basis for the growth and (Rijani, 2018).

The high and low morale of one's work is influenced by the following factors: (I) A person's interest in the work done, (2) The wage/salary factor, (3) The social status of a job, (4) The work atmosphere and the relationship between human and work, (5) The purpose of a job, teacher performance will produce good quality education (Basuki, 2015). Therefore the principal must be able to encourage teachers to always improve their performance, not only related to the teacher's assignments in the classroom, but also related to the teacher's activities outside the classroom (Rahmawati, 20I8).

Teacher performance cannot be separated from the leadership role of the principal as stimulate to increase motivation, morale and performance of the teacher itself (Rahmani, 2019). Rivai (2012) states that performance is an achievement achieved by a person in carrying out a task or work in accordance with established standards and criteria.
Based on the above problems, this study aims to find out: What is the description of the principal's leadership, work motivation, work morale and teacher performance, Is there a direct relationship between the principal's leadership and teacher's work motivation? Is there a direct relationship between the principal's leadership and teacher's work spirit? Is there a direct relationship between work motivation and teacher performance? Is there a direct relationship between work morale and teacher performance? Is there an indirect relationship between principal leadership and performance through teacher motivation? Is there an indirect relationship between principals' leadership and performance through teacher work enthusiasm in State Middle Schools in the East Banjarmasin sub-district of Banjarmasin City?

\section{Methodology}

The type of research used is quantitative research with descriptive analysis and using regression techniques. Research with a descriptive approach aims to systematically describe the facts and characteristics of objects or subjects that are precisely examined (Sukardi, 20II). While the regression technique is research that predicts the extent of changes in the value of the dependent variable, if the value of the variables contained among independent variables is manipulated or changed or increased downward (Sukardi, 20I I).

The research sample was I22 teachers from the Public Middle School in East Banjarmasin Subdistrict, Banjarmasin City, who were randomly selected using the Slovin formula from the population I88 teacher.

Data collection using a questionnaire consisting of principal's leadership (Y) contained between three variables, these variables are teacher motivation variables (XI), morale's teacher variables (X2), teacher performance variables (X3) as independent variables while principals's leadership variables school $(Y)$ as the dependent variable. The relationship between variables $\mathrm{XI}, \mathrm{X} 2$, and $\mathrm{X} 3$ and $\mathrm{Y}$ is described as follows:

Teacher motivation 


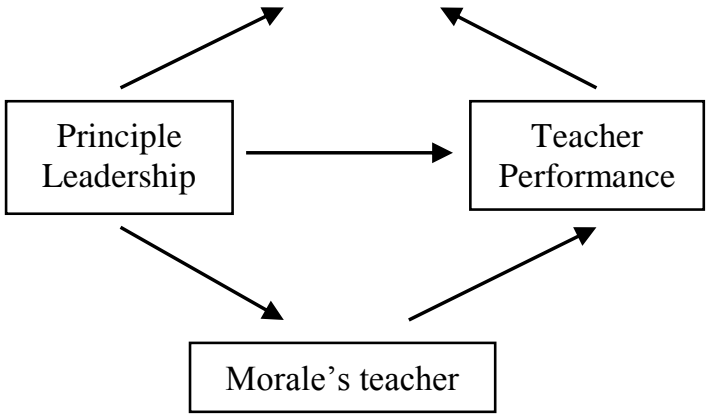

Figure I. Inter-Variable Conceptual Relationship Model

HI: There is a direct relationship between the principal's leadership and the performance of teachers in state junior high schools in the East Banjarmasin sub-district osf Banjarmasin City. H2: There is no direct relationship between principals 'leadership and teachers' work motivation in State Middle Schools in the East Banjarmasin sub-district of Banjarmasin City. H3: There is no direct relationship between the principal's leadership and the teacher's work enthusiasm in State Middle Schools in the East Banjarmasin sub-district of Banjarmasin City. H4: There is a direct relationship between work motivation and teacher performance in State Middle Schools in the East Banjarmasin sub-district of Banjarmasin City. H: 5 There is a direct relationship between work enthusiasm and teacher performance in State Middle Schools in the East Banjarmasin sub-district of Banjarmasin City. H6: There is an indirect relationship between principals' leadership and performance through teacher motivation in State Middle Schools in the East Banjarmasin sub-district of Banjarmasin City. H7: There is an indirect relationship between principals' leadership and performance through the work enthusiasm of teachers in State Middle Schools in the East Banjarmasin sub-district of Banjarmasin City.
Table I Frequency distribution of Principal Leadership

\begin{tabular}{ccc}
\hline Categori & Frequent & Persentage \\
\hline Low & - & - \\
Medium & - & - \\
More than medium & - & - \\
High & $\mathrm{I}$ & $\mathrm{I} \%$ \\
Very high & $\mathrm{I} 2 \mathrm{I}$ & $99 \%$ \\
Total of & $\mathrm{I} 22$ & $\mathrm{I00} \%$ \\
\hline
\end{tabular}

Table 2 Frequency distribution of teacher motivation

\begin{tabular}{ccc}
\hline Categori & Frequent & Persentage \\
\hline Low & - & - \\
Medium & - & - \\
More than medium & - & - \\
High & 6 & $5 \%$ \\
Very high & 96 & $95 \%$ \\
Total of & I22 & I00\% \\
\hline
\end{tabular}

Table 3 Frequency distribution of morale teacher

\begin{tabular}{ccc}
\hline Categori & Frequent & Persentage \\
\hline Low & - & - \\
Medium & - & - \\
More than medium & - & - \\
High & I7 & I4\% \\
Very high & I05 & $86 \%$ \\
Total of & I22 & I00\% \\
\hline
\end{tabular}

Table 4 Frequency distribution of teacher performace

\begin{tabular}{ccc}
\hline Categori & Frequent & Persentage \\
\hline Low & - & - \\
Medium & - & - \\
More than medium & - & - \\
High & 3 & $2,5 \%$ \\
Very high & II 9 & $97,5 \%$ \\
Total & I22 & 100\% \\
\hline
\end{tabular}

Table I it is known that the picture of leadership of the principal is very good, stated by respondents $99 \%$. In table 2 work motivation is very well expressed by $95 \%$ of respondents. In table 3 the work spirit was very good, $86 \%$ of respondents said. In table 4 Very good performance is obtained $97.5 \%$.

\section{Results}

Table 5 Coefficient of regression the influence of leadership on teacher work motivation

\begin{tabular}{|c|c|c|c|c|c|}
\hline & \multicolumn{2}{|c|}{$\begin{array}{c}\text { Unstandarized } \\
\text { Coefficent }\end{array}$} & $\begin{array}{c}\text { Standarized } \\
\text { Coefficent }\end{array}$ & $\mathrm{T}$ & Sig \\
\hline & $\mathrm{B}$ & $\begin{array}{c}\text { Stand } \\
\text { Error }\end{array}$ & Beta & & \\
\hline Constant & III.026 & 20,566 & & 5,398 & 0,000 \\
\hline XI-X2 & 0,103 & 0,164 & 0.078 & 0,853 & 0,396 \\
\hline
\end{tabular}


ISSN 2580-2135

Table 6 Coefficient of regression the influence of leadership and motivation to teacher performance

\begin{tabular}{|c|c|c|c|c|c|}
\hline \multirow{2}{*}{$\begin{array}{c}\text { Model } \\
\text { Constant }\end{array}$} & \multicolumn{2}{|c|}{$\begin{array}{c}\text { Unstandarized } \\
\text { Coefficent }\end{array}$} & $\begin{array}{c}\text { Standarized } \\
\text { Coefficent }\end{array}$ & $\mathrm{T}$ & Sig \\
\cline { 2 - 6 } & $\begin{array}{c}\text { B } \\
162,006\end{array}$ & $\begin{array}{c}\text { Stand } \\
\text { Error } \\
21,574\end{array}$ & Beta & 7,537 & 0,000 \\
\hline XI-y & 0,196 & 0,086 & 0,201 & 2,279 & 0,034 \\
\hline X2-y & 0,365 & 0,155 & 0.208 & 2,157 & 0,020 \\
\hline
\end{tabular}

Table 7 Coefficient of regression the influence of leadership to morale teacher

\begin{tabular}{|c|c|c|c|c|c|}
\hline \multirow{2}{*}{} & \multicolumn{2}{|c|}{$\begin{array}{c}\text { Unstandarized } \\
\text { Coefficent }\end{array}$} & $\begin{array}{c}\text { standarized } \\
\text { coefficent }\end{array}$ & $\mathrm{T}$ & Sig \\
\cline { 2 - 6 } & $\mathrm{B}$ & $\begin{array}{c}\text { Stand } \\
\text { Error } \\
2 \mathrm{I}, 574\end{array}$ & Beta & & \\
\hline Constant & 206,986 & $20,14 \mathrm{I}$ & & 10,277 & 0,0 \\
\hline $\mathrm{XI}$ & 0,365 & 0,155 & -0.112 & 2,157 & 219 \\
\hline
\end{tabular}

Table 8 Leadership and morale teacher to teacher performance Guru

\begin{tabular}{|c|c|c|c|c|c|c|}
\hline \multirow{2}{*}{\multicolumn{2}{|c|}{ Model }} & \multicolumn{2}{|c|}{$\begin{array}{c}\text { Unstandarized } \\
\text { Coefficient }\end{array}$} & $\begin{array}{c}\text { Standarized } \\
\text { Coefficient }\end{array}$ & \multirow{2}{*}{ T } & \multirow{2}{*}{ Sig } \\
\cline { 3 - 5 } & B & $\begin{array}{c}\text { Stand } \\
\text { Error }\end{array}$ & Beta & & \\
\hline \multirow{2}{*nyyynn}{} & Constant & 210,789 & 26,875 & & 7,843 & 0,000 \\
\hline & $X_{1}$ & -363 & 157 & $-0,207$ & $-2,307$ & 0,023 \\
\hline & $X_{3}$ & -128 & 089 & $-0,129$ & $-, I, 438$ & 0,153 \\
\hline
\end{tabular}

In table 5, it is known that the significant influence of leadership on performance is 0.396 $<0.05$. Become a hypothesis: There is a direct relationship between the principal's leadership and the performance of teachers in state junior high schools the East Banjarmasin sub-district of Banjarmasin City. hypothesis states that there is a direct relationship between principals 'leadership and teachers performance in state junior high schools in the East Banjarmasin sub-district of Banjarmasin City is not accepted because significant influence of leadership on motivation significance of $0.396>0.05$.

In table 6 shows a significance of The hypothesis states that there is a direct relationship between work motivation and teacher performance in state junior high schools in the East Banjarmasin sub-district of Banjarmasin City, accepted because the significance is $0.020<0.05$. There is a direct relationship between work morale and teacher performance in state junior high schools in the East Banjarmasin sub-district of Banjarmasin City, not proven because the significance is $0.155>0.05$.

In table 7 Hypothesis states there is a direct relationship between work motivation and teacher performance in state junior high schools in the East Banjarmasin sub-district of Banjarmasin City teachers in State
Middle Schools in the East Banjarmasin sub-district of Banjarmasin City were not accepted because the significance was $0.219>0.05$.

Tabel 9 The results of testing the hypothesis I,2,3,4, dan 5

\begin{tabular}{|c|c|c|c|}
\hline & Hypotheses & $\mathrm{P}$ & Decision \\
\hline $\mathrm{CH}_{\mathrm{I}}$ & $\begin{array}{l}\text { There is a direct relation- } \\
\text { ship between the princi- } \\
\text { pal's leadership and the } \\
\text { performance of teachers } \\
\text { in state junior high } \\
\text { schools in the East Ban- } \\
\text { jarmasin sub-district osf } \\
\text { Banjarmasin City. }\end{array}$ & 0,024 & Accept \\
\hline $\mathrm{H}_{2}$ & $\begin{array}{l}\text { There is no direct rela- } \\
\text { tionship between princi- } \\
\text { pals 'leadership and } \\
\text { teachers' work motiva- } \\
\text { tion in State junior high } \\
\text { Schools in the East Ban- } \\
\text { jarmasin sub-district of } \\
\text { Banjarmasin City }\end{array}$ & 0,396 & Is not accept \\
\hline $\mathrm{H}_{3}$ & $\begin{array}{l}\text { There is no direct rela- } \\
\text { tionship between the } \\
\text { principal's leadership and } \\
\text { the moral teacher's in } \\
\text { State junior high Schools } \\
\text { in the East Banjarmasin } \\
\text { sub-district of Banjarma- }\end{array}$ & 0,219 & Is not accept \\
\hline
\end{tabular}


$\sin$ City

$\mathrm{H}_{4} \quad$ There is a direct relationship between work motivation and teacher performance in State yunior high Schools in the East Banjarmasin sub-district of Banjarmasin City

$\mathrm{H}_{5} \quad$ There is a direct relationship between moral teacher and teacher performance in State junior high Schools in the East Banjarmasin sub-district of Banjarmasin City.
0,020 Accept

0,I53 Not accept

\section{Discussion}

HI There is a direct relationship between the leadership of the school principal and the performance of teachers in state junior high schools in the East Banjarmasin sub-district of Banjarmasin City 0.024 Accepted.

H2 There is a direct relationship between principals 'leadership and teachers' work motivation in State Middle Schools in East Banjarmasin sub-district Banjarmasin City 0.396 Not accepted.

H3 There is a direct relationship between the principal's leadership and the teacher's work spirit in State Middle Schools in the East Banjarmasin subdistrict of Banjarmasin City 0.219 Not accepted.

H4 There is a direct relationship between work motivation and teacher performance in State Middle Schools in the East Banjarmasin sub-district of Banjarmasin City. 0.020 Accepted.

H5 There is a direct relationship between work enthusiasm and teacher performance in State Middle Schools in the East Banjarmasin sub-district of Banjarmasin City.

\section{Beta Hypothesis Decision}

Indirect Jump

H6 There is an indirect relationship between principals' leadership and performance through teacher motivation in state junior high schools in the East Banjarmasin sub-district of Banjarmasin City not received 0.20I 0.0162 Not accepted.

H7 There is an indirect relationship between the leadership of the principal and performance through the enthusiasm of the work of teachers in State Middle Schools in the East Banjarmasin sub-district of Banjarmasin City, not received 0.207 0.0I44 Not accepted.

Table I it is known that the picture of leadership of the principal is very good, stated by respondents $99 \%$. In table 2 work motivation is very well expressed by $95 \%$ of respondents. In table 3 the work spirit was very good, $86 \%$ of respondents said. In table 4 Very good performance is obtained $97.5 \%$.

Table 9 Results of Testing Hypotheses 6 and 7 Beta Hypothesis Decision

Indirect Jump

H6 There is an indirect relationship between principals' leadership and performance through teacher motivation in state junior high schools in the East Banjarmasin sub-district of Banjarmasin City not received 0.20I 0.0I62 Not accepted.

H7 There is an indirect relationship between the leadership of the principal and performance through the enthusiasm of the work of teachers in State Middle Schools in the East Banjarmasin sub-district of Banjarmasin City, is not received hypothesis states that there is a direct relationship between principals 'leadership and teachers' work In table 5, it is known that the significant influence of leadership on performance is $0.02 \mathrm{I}<0.05$. Become a hypothesis: There is a direct relationship between the principal's leadership and the performance of teachers in state junior high schools the East Banjarmasin sub-district of Banjarmasin City.

Motivation in state junior high schools in the East Banjarmasin sub-district of Banjarmasin City is not accepted because significant influence of leadership on motivation in table 6 shows a significance of $0.396>$ 0.05 Hypothesis states teachers in State Middle Schools in the East Banjarmasin sub-district of Banjarmasin City were not accepted because the significance was $0.219>0.05$.

The hypothesis states that there is a direct relationship between work motivation and teacher performance in state junior high schools in the East Banjarmasin sub-district of Banjarmasin City, accepted because the significance is $0.020<0.05$. There is a direct relationship between work morale and teacher performance in state junior high schools in the East Banjarmasin sub-district of Banjarmasin City, not proven because the significance is 0.I53>0.05, table 9. shows the results of indirect influence. To determine the indirect effect refers to the comparison of beta values. The provision is if the direct influence> indirect influence, then indirect influence is not accepted. If the direct effect <indirect effect, then the indirect effect is accepted. 
The hypothesis states: There is an indirect relationship between principals' leadership and performance through the motivation of teachers in state junior high schools in the East Banjarmasin subdistrict of Banjarmasin City, not accepted, because the influence of lanhsung is $0.20 \mathrm{I}>$ indirect effect of 0.0162. The hypothesis states that there is an indirect relationship between the principal's leadership and performance through the enthusiasm of the work of teachers in state junior high schools across the East Banjarmasin sub-district of Banjarmasin City is not accepted. This is because the direct effect of $0.207>$ indirect effect is 0.0I44.

This study proves that principals' leadership is directly related significantly to the performance of teachers in state junior high schools across East Banjarmasin sub-districts. (Normianti, 2019) states that leadership as a general term is a process of influencing a person's or group's activities in efforts towards achieving goals in certain situations. The principal is a person who has professional abilities who work based on a mutually agreed professional performance pattern to facilitate and support the success of learning (Mulyasa E, 2013). The success of learning is closely related to the performance of teachers who carry out their duties. To realize optimal teacher performance, leadership of mocratic and professional headmaster is needed. Thus it can be seen that the leadership of the principal is very influential on teacher performance. So, on that basis it is alleged that there is a relationship between the leadership of the principal and the teacher's performance. This means that the better the leadership of the principal the better the performance of a teacher. For the contrary, the worse the leadership of the principal is, the lower the performance of a teacher.

The results of this study indicate that the relationship between the principal's leadership and the motivation of the work of state junior high school teachers in the East Banjarmasin sub-district was not proven. This means that the leadership carried out by the principal well is not related to the motivation of the teacher's work in carrying out the tasks at school. This can be explained that the teacher has high motivation in work even though the principal's leadership is good or not. The teacher shows high work motivation because the teacher animates his job well as an educator in the school (Syarwani, 2018).

The results of this study indicate that the relationship between the principal's leadership and the work morale of the public junior high school teachers in the East Banjarmasin sub-district was not proven. This means that maximum leadership carried out by the principal does not have anything to do with the enthusiasm of the teacher in carrying out the tasks at school. This can be explained that the teacher has a high enthusiasm for work even though the principal's leadership is good or not. The teacher shows that he still works with high enthusiasm.

The findings of this study are that there is a direct relationship between work motivation and teacher performance in State Middle Schools in East Banjarmasin Subdistrict, Banjarmasin City. (Aslamiah, 2018) states that, "Work motivation can be interpreted as a desire or need behind a person so that he is motivated to work".

(Hani, 20I2) states that motivation is an activity that results in, channeling, and maintaining human behavior. This motivation is an important subject for managers, because by definition managers must work with and through others (Aslamiah, 2018). "Managers need to understand people behaving in certain ways in order to influence them to work in accordance with what the organization wants".

According to Hasibuan (2008), "There are several motivational goals, namely: a) Encouraging employee enthusiasm and enthusiasm; b) Increasing employee morale and job satisfaction; c) Increase employee work productivity; d) Maintaining employee loyalty and stability; e) Increase discipline and reduce employee absenteeism; f) Effective procurement of employees; $g$ ) Creating a good working atmosphere and relationship; h) Increasing employee creativity and participation; i) Increase the level of employee welfare; j) Enhancing employee responsibility; $\mathrm{k}$ ) and others ".

According to Sofyandi (2008) that motivation increases morale and job satisfaction of employees, b) Increases employee work productivity, c) Maintaining employee stability in the company, d) Increases employee discipline in work, e) Making employees effective, $f$ ) creating atmosphere and working relationships conducive, g) Increasing employee loyalty, creativity and participation, h) Improving employee welfare, i) Increasing the sense of responsibility for the task, etc. he findings of this study also prove that there is a relationship between work enthusiasm and the performance of teachers in Public Middle Schools in East Banjarmasin District. However, the results of this study indicate that there is no relationship between principals' leadership and performance through the motivation of state junior high school teachers in East Banjarmasin sub-districts. The leadership of the school 
principal has a direct and significant relationship with the performance of the teachers of the Public Middle School in the Banjarmasin sub-district of Timut. So the direct leadership relationship with performance is better than the principal's relationship with work through work motivation.

The results of this study also show that there is no relationship between principals' leadership and performance through the work morale of state junior high school teachers in East Banjarmasin sub-districts. The leadership of the school principal has a direct and significant relationship with the performance of the teachers of the Public Middle School in the Banjarmasin sub-district of Timut. So the direct leadership relationship with performance is better than the principal's leadership relationship with morale teacher.

\section{Conclussion}

There is a significant relationship between the leadership of the principal and the motivation of the work. There is a significant relationship between the leadership of the principal and the working morale. Principal leadership is directly related significantly to the performance of teachers. There is a direct relationship between work motivation and teacher performance. There is a significant relationship between work enthusiasm and the performance of teachers

\section{Suggestion}

I. With the direct relationship between the principal's leadership and the teacher's work motivation, it is expected that the principal can introspect to increase motivation to the teacher.

2. With the direct relationship between the principal's leadership and the teacher's work spirit, it is expected that the principal can optimize the utilization of the resources available in the school.

3. With the direct relationship between work motivation and teacher performance, it is expected to improve school policies and establish ways to improve performance.

4. With a direct relationship between work spirit and teacher performance, it is expected that teachers can increase their morale and performance in their duties as educators.

\section{Acknowledgment}

Authors thanks to Magister Program of Educational Manajement, Lambung Mangkurat University
Banjarmasin for facilitating and supporting our research.

\section{References}

Aslamiah. 2018. The Relationship between tranformation leadership and work motivation with the teacher's performance. Public Elementary School, 5(2), p. I0.

Aslamiah. 2018. The Relationship of Work Culture, Emotional Intelligence and Organizational Citizenship Behavior (OCB) To The Teaching Performance of Teachers at the East Banjarmasin District Elementary School. Journal of Education Studies, 8(3), p. 5.

Basuki, S., 20I5. Relationship between the implementation of supervision, school culture, morale and work motivation with the performance of physical education teachers at the State Elementary School in South Kalimantan. European Journal of Education Studies, 5(4), p. 53.

Hani, H. T., 20I2. Manajemen Personalia dan Sumber Daya Manusia. Yogyakarta: BPFF Yogyakarta.

Hasibuan M, 2008. Manajemen Sumber Daya Manusia. Edisi Revisi ed. Jakarta: Bumi Aksara.

Kusrini, L., 2018. The Influence of Supervision of Academic Supervision with Commitment and teacher work motivation on The Teacher Performance At SMA In Banjarmasin city, Indonesia. European Journal Of Education Studies, 5(7), pp. 2-7.

Mulyasa E, 2013. Manajemen dan Kepemimpinan Kepala Sekolah. ke 3 ed. Jakarta: Bumi Aksara.

Murtie, A., 20I3. Manajemen Motivasi. Jakarta: PT Gramedia Widiasarana Indoinesia.

Normianti, H., 2019. Relationship of Transformational Leanders of Principal, Teacher Motivation, Teacher Organization Commitments With Perfonace of Primary School Teachers in Labuan Amas Selatan, Indonesia. European Journal of Education Studies, 5(II), pp. 3-4.

Purwanto, M. N., 2009. Educattional Administration and Supervision. Bandung: Rosdakarya.

Rahmani, M. U., 2019. The Correlation Between Supervision of School Supervisor and Supervision of Principal With Teacher 
Performance in Public Elementary School in Astambul Subdistrict. International Journal of Schientific Development and Research (IJSDR), 4(I), pp. 7-8.

Rahmawati, E., 2018. Relation between Emotional Intelligence, Spritual Intellliegence and Teacher Performance Through Work Motivation As Interviening Variables In Islamic Elementary School In Banjarmasin, Indonesia. European Journal Of Education Studies, 5(II), pp. 3-8.

Rijani, A., 2018. The Correlation between Pricipal's academic Supervision, Commitment, Morale and teacher performance of SMP Negeri In Tapin District. Jurnal of Research \& Method in Education, 8(6), pp. 8-9.

Rivai, V., 20I2. Leadership and Organizational Behavior. 4 th Edition ed. Jakarta: Raja Grafindo Perkasa.
Suhaimi, 2018. Relationship between the role of the principal and attitudes towards the teaching profession with teacher work performance in public high schools in the southern Hulu Sungai Regency. Jurnal Ilmiah Kependidikan, I3(5), pp. 78-83.

Sukardi, 20II:I57. Metode Penelitian Pendidikan Kompetensi dan Praktisnya. Jakarta: PT Bumi Aksara.

Suriansyah, A., 2015. The Leadership Strategies of School Principals, Parents, and Communicative in the building the Students Characters. Jurnal Cakrawala Pendidikan, 34(2), p. 6.

Syarwani, A., 20I8. The influence of principal Leadership style Organizational Citizenship Behavior and Work Motivation on the Performance Teacher of State Vacational High School In Babnjarmasin City. Scientific devolepment and Recearch, 3(I2), pp. 8-I5. 